\title{
Laboratory and Clinical Evaluation of DNA Microarray for the Detection of Carbapenemase Genes in Gram-Negative Bacteria from Hospitalized Patients
}

\author{
Yi Song $\mathbb{D}^{1,2}$ Fengna Dou, ${ }^{1,2}$ Sha He, ${ }^{3}$ Yu Zhou $\mathbb{D}^{4},{ }^{4}$ and Qiqi Liu $\mathbb{D}^{1,2}$ \\ ${ }^{1}$ Beijing Institute of Radiation Medicine, Beijing, China \\ ${ }^{2}$ Beijing Key Laboratory of New Molecular Diagnosis Technologies for Infectious Diseases, Beijing, China \\ ${ }^{3}$ The First Hospital of Hebei Medical University, Hebei, China \\ ${ }^{4}$ Clinical Laboratory of Second Medical Center of PLA General Hospital, Beijing, China
}

Correspondence should be addressed to Yu Zhou; zhouy427@163.com and Qiqi Liu; liuqiqi@bmi.ac.cn

Received 14 December 2018; Revised 12 March 2019; Accepted 2 April 2019; Published 13 May 2019

Guest Editor: Payam Behzadi

Copyright (C) 2019 Yi Song et al. This is an open access article distributed under the Creative Commons Attribution License, which permits unrestricted use, distribution, and reproduction in any medium, provided the original work is properly cited.

\begin{abstract}
Background. The prevalence of a variety of carbapenemases in Gram-negative bacteria (GNB) has posed a global threat on clinical control and management. Monitoring and controlling the carbapenemase-producing GNB became imperative tasks for many healthcare centers. The aim of this study was to develop a high-throughput, specific, sensitive, and rapid DNA microarray-based method for the diagnosis, phenotypic confirmation, and molecular epidemiological study of carbapenemase genes. Methods. We targeted a panel of eight carbapenemase genes, including $b l a_{\mathrm{KPC}}, b l a_{\mathrm{NDM}-1}, b l a_{\mathrm{OXA}-23}, b l a_{\mathrm{OXA}-48}, b l a_{\mathrm{OXA}-51}, b l a_{\mathrm{IMP}}, b l a_{\mathrm{VIM}}$, and $b l a_{\mathrm{DIM}}$ for detection. Ultrasensitive chemiluminescence (CL) detection method was developed and used to simultaneously detect eight carbapenemase genes, and plasmids were established as positive or limit of detection (LOD) reference materials. Antibiotic susceptibility was determined by disk diffusion according to Clinical and Laboratory Standards Institute (CLSI) guidelines in order to screen clinical isolates resistant to carbapenem antibiotics as well as Sanger sequencing which was used to confirm the reliability of the results presented by DNA microarray. Results. Eight carbapenemase genes could be detected with high sensitivity and specificity. The absolute LOD of this strategy to detect serially diluted plasmids of eight carbapenemase genes was $10^{2}-10^{3} \mathrm{copies} / \mu \mathrm{L}$. Then, 416 specimens collected from hospital were detected and the results showed $96.6 \%$ concordance between the phenotypic and microarray tests. Compared with Sanger sequencing, a specificity and sensitivity of $100 \%$ were recorded for $b l a_{\mathrm{NDM}-1}, b l a_{\mathrm{IMP}}, b l a_{\mathrm{VIM}}$, and $b l a_{\mathrm{DIM}}$ genes. The specificity for $b l a_{\mathrm{KPC}}, b l a_{\mathrm{OXA}-23}, b l a_{\mathrm{OXA}-48}$, and $b l a_{\mathrm{OXA}-51}$ genes was $100 \%$ and the sensitivity was $98.5 \%, 97.6 \%, 95.7 \%$, and $97.9 \%$, respectively. The overall consistency rate between the sequencing and microarray is $97.8 \%$. Conclusions. The proposed ultrasensitive CL imaging DNA hybridization has high specificity, sensitivity, and reproducibility and could detect and differentiate clinical specimens that carried various carbapenemase genes, suggesting that the method can conveniently be customized for highthroughput detection of the carbapenemase-producing GNB and can be easily adapted for various clinical applications.
\end{abstract}

\section{Introduction}

Carbapenems are a class of $\beta$-lactam antibiotics with a broad spectrum and served as the last line against ESBLs efficiently and stably [1]. With wide and heavy use of various antibiotics, carbapenem-resistant isolates have become worldwide public-health issue with a widespread distribution, broad range of activities against $\beta$-lactams, and increased patient morbidity, mortality, and lengths of hospital stay [2], particularly among elderly patients, infants, and patients with severe underlying disease. In the clinic, it is imperative to develop a rapid, simple, and accurate test to detect and identify the clinical strains that produce carbapenemase, and this is critical for the management and control of the increasing prevalence of carbapenemase-producing strains worldwide [3].

The detection of carbapenemase producers in clinical specimens is based first on the analysis of susceptibility testing according to CLSI updated in 2017 [4], followed by confirmatory genotypic tests with methods like PCR and mass spectrometry $[3,5]$. However, these tests are not the 
best fit for detecting the carbapenemase-producing strains with desirable specificity and sensitivity [6]. Even the recommended CLSI methods are limited by their inherent disadvantages: the phenotypic tests for carbapenemase-producing strains suffer problems of false positives and false negatives $[5,7]$. Mass spectrometry cannot provide molecular epidemiological information and is cost-ineffective. Addressing these deficiencies, we herein propose a novel DNA microarraybased method for rapid, sensitive, and specific detection of clinical carbapenamase-producing samples. The proposed assay may have important implications in the diagnosis, phenotypic confirmation, and the molecular epidemiology studies of carbapenemase-producing bacteria.

The Ambler molecular classification system, based on protein homology, categorizes $\beta$-lactamases into four classes (A to $\mathrm{D})$. The most extensive distribution class A enzyme with carbapenemase activity is KPC. The class B enzymes are metalloenzymes of the most IMP or VIM series. Besides, NDM and DIM belong to class B enzymes which are widely concerned in Asia [8]. Many OXA enzymes (OXA-23-like, OXA-48-like, class D) are considered to be responsible for the worldwide resistance epidemics as well as their detailed properties which have been extensively reported $[9,10]$. The presence of $b l a_{\text {DIM-1 }}$ has been considered lower once before, for a Pseudomonas stutzeri isolate from the Netherlands [11]. However, in a recent report, $b l a_{\mathrm{DIM}-1}$ was found in hospital isolates belonging to the families Enterobacteriaceae, Pseudomonadaceae, Burkholderiaceae, and Comamonadaceae and forty percent of the isolates were found to contain $b l a_{\mathrm{DIM}-1}$ among the tested isolates [12]. The $b l a_{\mathrm{OXA}-51}$ and $b l a_{\text {OXA-23 }}$ genes are mainly responsible for the resistance in Acinetobacter baumannii [13], whereas the bla $a_{\text {OXA-23-like }}$ genes are the most prevalent carbapenem-resistant genes identified in China $[13,14]$. The $b l a_{\text {OxA-51-like genes have been }}$ considered exclusively chromosomally encoded, intrinsic oxacillinase genes of Acinetobacter baumannii and are used by many investigators for species identification and strain typing [15]. However, a number of recent reports indicate that the $b l a_{\text {OXA-51-like genes have been mobilized and are spreading }}$ to other Acinetobacter spp. by conjugative plasmids [16, 17]. While further work is required to determine carbapenem resistance of OXA-51-like group, the enzymes of this group remain a major concern, as they present the possibility that all A. baumannii isolates may be capable of becoming resistant to the carbapenems [18]. Therefore, in the current study, we included $b l a_{\mathrm{KPC}}, b l a_{\mathrm{NDM}-1}, b l a_{\mathrm{OXA}-23}, b l a_{\mathrm{OXA}-48}, b l a_{\mathrm{OXA}-51}$, $b l a_{\mathrm{IMP}}, b l a_{\mathrm{VIM}}$, and $b l a_{\mathrm{DIM}}$ in the detection panel for the DNA microarray assays.

DNA microarrays have had wide applications, including gene expression analysis [19], disease diagnosis [20], and pathogenic microorganism detection [21]. This technique is characterized by miniaturization, high-throughput, manageability, and easiness of automatization. The purpose of this work is to develop a rapid, reliable, and high-throughput DNA microarray method for detection of clinically relevant carbapenemase-encoding genes. In this assay, a reliable and portable, ultrasensitive chemiluminescence (CL) imaging DNA hybridization was developed to simultaneously detect eight genes. Plasmids were established as positive or limit of detection (LOD) reference materials. The specificity and sensitivity of the method was validated in 416 actual samples.

\section{Materials and Methods}

2.1. Ethics Statement. All patients provided informed consent in accordance with requirements of the Declaration of Helsinki, and the research project was approved by the Ethical Committee of Chinese People's Liberation Army (PLA) General Hospital.

2.2. Specimen Collection and Processing. The samples collected from PLA General Hospital of China were sputum, urine, and bacteria isolates. Sputum sample was liquefied by $4 \% \mathrm{NaOH}$ for $30 \mathrm{~min}$ at room temperature with shaking and then centrifuged at 13,000 rpm for $2 \mathrm{~min}$. Pellets were collected and washed. The DNA in sputum pellets and urine samples were isolated by QIAamp DNA Mini Kit according to the manufacturer's instructions. Bacteria isolates were prepared by modified boiling method. Briefly, colonies of each isolate were picked from Luria-Bertani plates and suspended in $100 \mu \mathrm{L}$ of sterilized $\mathrm{H}_{2} \mathrm{O}$, followed by boiling at $95^{\circ} \mathrm{C}$ for 15 $\mathrm{min}$ and centrifugation at 12,000 rpm for $5 \mathrm{~min}$. Supernatants were harvested and transferred to new tube and served as templates for PCR and microarray assays [13].

2.3. Primer and Probe Design. The DNA sequences of the carbapenemase (i.e., $b l a_{\mathrm{KPC}}, b l a_{\mathrm{NDM}-1}, b l a_{\mathrm{OXA}-23}, b l a_{\mathrm{OXA}-48}$, $b l a_{\mathrm{OXA}-51}, b l a_{\mathrm{IMP}}, b l a_{\mathrm{VIM}}$, and $\left.b l a_{\mathrm{DIM}}\right)$ were downloaded from GenBank (http://www.ncbi.nlm.nih.gov/genomes/). Primers and probes were designed by DNAMAN and Primer Premier. Specific primers were designed for $b l a_{\mathrm{NDM}-1}, b l a_{\mathrm{OXA}-48}$, and $b l a_{\mathrm{DIM}-1}$. For $b l a_{\mathrm{KPC}}, b l a_{\mathrm{IMP}}, b l a_{\mathrm{VIM}}, b l a_{\mathrm{OXA}-23-\mathrm{like}}$, and $b l a_{\text {OXA-51-like, }}$, primers were chosen in the conserved upstream or downstream regions. Microarray probes ranging from 33 to 42 nucleotides were synthesized for these genes. These genes were amplified by multiplex PCR in separate tubes, and an internal standard probe was included for each tube for process monitoring. Finally, ten primers and seventeen probes with favorable specificities were selected (Tables 1 and 2). All the primers and probes were verified by BLAST (http://blast.ncbi.nlm.nih.gov/).

2.4. Construction of Reference Plasmids. Oligonucleotides of $b l a_{\mathrm{DIM}}$ and $b l a_{\mathrm{VIM}}$ in this study were spliced by big primer amplification method in which $40 \mathrm{bp}$ fragments were concatenated into final sequences of about $280 \mathrm{bp}$. Carbapenemase-producing samples of OXA-23, OXA-48, and OXA-51 were collected from Chinese PLA General Hospital in Beijing and samples of KPC, IMP, and NDM1 were collected from Chinese PLA Academy of Military Medical Sciences. These eight well-characterized reference strains, each carrying $b l a_{\mathrm{KPC}}, b l a_{\mathrm{NDM}-1}, b l a_{\mathrm{OXA}-23}, b l a_{\mathrm{OXA}-48}$, $b l a_{\mathrm{OXA}-51}, b l a_{\mathrm{IMP}}, b l a_{\mathrm{VIM}}$, or $b l a_{\mathrm{DIM}}$, were used for the design and validation of the microarray probes and primers. DNA fragments of KPC, NDM-1, OXA-23, OXA-48, OXA-51, IMP, VIM, DIM, mitochondrial DNA (mtDNA), and 16S rRNA were amplified by PCR, followed by digestion with PGM$\mathrm{T}$ and cloning into DH5 $\alpha$. The cloned fragments were confirmed by sequencing the entire regions. Mitochondrial DNA 
TABLE 1: The primer sequences for microarray.

\begin{tabular}{|c|c|c|c|}
\hline Primer $^{a}$ & Sequence $\left(5^{\prime}-3^{\prime}\right)$ & Positions ${ }^{b}$ & $\begin{array}{c}\text { Targeted gene/ } \\
\text { GenBank accession }\end{array}$ \\
\hline KPC-F & CTGGGCAGTCGGAGACAAAA & $681-700$ & KPC/ KX619622.1 \\
\hline KPC-R & AGACGGCCAACACAATAGGT & $765-784$ & \\
\hline NDM1-F & GAATGTCTGGCAGCACACT & $168-186$ & NDM-1/ KX249707 \\
\hline NDM1-R & TGGCATAAGTCGCAATCC & $407-424$ & \\
\hline OXA23-F & GCAGTCCCAGTCTATCAGGA & $379-398$ & OXA-23/NG_049726 \\
\hline OXA23-R & CCCAACCAGTCTTTCCAA & $641-658$ & \\
\hline OXA48-F & TCGGGCAATGTAGACAGTT & $548-556$ & OXA-48/ NG_049762 \\
\hline OXA48-R & CACCAGCCAATCTTAGGTTC & $746-765$ & \\
\hline OXA51-F & GCTCGTCGTATTGGACTTGA & 406-425 & OXA-51/ KX609247 \\
\hline OXA51-R & TGTGCCTCTTGCTGAGG & $523-539$ & \\
\hline IMP-F & GTAATTGACACTCCATTTAC & 291-309 & IMP /NG_049172 \\
\hline IMP-R & GCGGACTTTGGCCAAGCTTC & $674-693$ & \\
\hline VIM-F & TGGTGAGTATCCGACAG & $190-206$ & VIM/NG_050336 \\
\hline VIM-R & ATGAAAGTGCGTGGAG & $433-448$ & \\
\hline DIM-F & GCTTGTCTTCGCTTGCTAA & $38-56$ & DIM/NG_049077 \\
\hline DIM-R & ATTCCTGCGGTTCTATCCT & 293-311 & \\
\hline mtDNA-F & GTCGAAGGTGGATTTAGCAGTAA & $1413-1435$ & mtDNA/MG182040 \\
\hline mtDNA-R & GTAAGGTGGAGTGGGTTTGGG & $1684-1704$ & \\
\hline $182-\mathrm{F}$ & AGAGTTTGATCMTGGCTCAG & $1-20$ & 16S rRNA/ LN612729 \\
\hline $756-\mathrm{R}$ & CGTATTACCGCGGCTGCTG & $518-530$ & \\
\hline
\end{tabular}

${ }^{a}$ F, forward primer; R, reverse primer; all reverse primers have biotin conjugated at $5^{\prime}$-ends.

${ }^{\mathrm{b}}$ Positions refer to the nucleotide numberings of the corresponding GenBank genes.

TABLE 2: The probe sequences for microarray.

\begin{tabular}{|c|c|c|}
\hline Probe & Sequences $\left(5^{\prime}-3^{\prime}\right)^{a}$ & Targeted gene \\
\hline KPC-P & CAAATGACTATGCCGTCGTCTGGCC & KPC \\
\hline NDM1-P1 & ACCGATGACCAGACCGCCCAGATCCTCAAC & NDM-1 \\
\hline NDM1-P2 & TCAGGACAAGATGGGCGGTATGGAC & NDM-1 \\
\hline OXA23-P1 & TTTTAGAAGAGAGTAATGGCTACAAAA & OXA-23 \\
\hline OXA23-P2 & ATTGGACAGCAGGTTGATAATTTCTGG & OXA-23 \\
\hline OXA48-P1 & CGAATTTCGGCCACGGAGCAAATCAGCTT & OXA-48 \\
\hline OXA48-P2 & CAGCGTATTGTCAAACAAGCCATGC & OXA-48 \\
\hline OXA51-P1 & GAAGTGAAGCGTGTTGGTTATG & OXA-51 \\
\hline OXA51-P2 & ATATCGGTACCCAAGTCGATAATTTTTGGC & OXA-51 \\
\hline IMP-P1 & GGCTAGTTAAAAATAAAATTGAAG & IMP \\
\hline IMP-P2 & CCCACGTATGCRTCTGAATTAAC & IMP \\
\hline VIM-P1 & TGGTGTTTGGTCGCATATCGCAACG & VIM \\
\hline VIM-P2 & CTCATTGTCCGTGATGGTGATGAG & VIM \\
\hline DIM-P1 & GTCAGTTCAAACGGCCTTGTTGTCATAGATT & DIM \\
\hline DIM-P2 & CTTGGTCAGACCGAGATACAGAAACGCTCG & DIM \\
\hline mtDNA-P & ATGTCCTTTGAAGTATACTTGAGGAGTT & mitochondria \\
\hline $551-\mathrm{P}$ & ACTCCTACGGGAGGCAGCAGTT & 16S rRNA \\
\hline Quality control $^{\text {b }}$ & TTTTTTTTTTTTTTTTTTTT & Oligo $\mathrm{dT}_{20}$ \\
\hline
\end{tabular}


(19)(19(1)(19)(19)(19)(19)(19)

(1)(2)(3)(4)(5)(6) (7)

(1)(2)(3)(4)(5)(6)(7) 8

(1)(2)(3)(4)(5)(6) (7)

(9)(11)(11)(12)(13)(14)(15)(16)

(9)(11)(11)(12)(13)(14)(1)(16)

(9)(10)(11)(12)(13)(14)(15)(16)

(17)(17)(17)(17)(18)(18)(18) (18)

(1) KPC-P

(2) NDM1-P1

(3) NDM1-P2

(4) OXA23-P1

(5) OXA23-P2

(6)OXA48-P1

(7) OXA48-P2

(8) Negative control

(9) OXA51-P1

(10) OXA51-P2

\author{
(11)IMP-P1 \\ (12)IMP-P2 \\ (13)VIM-P1 \\ (14)VIM-P2 \\ (15)DIM-P1 \\ (16)DIM-P2 \\ (17) Internal control probe of tube A \\ (18) Internal control probe of tube $B$ \\ (19)Quality control probe
}

(a)

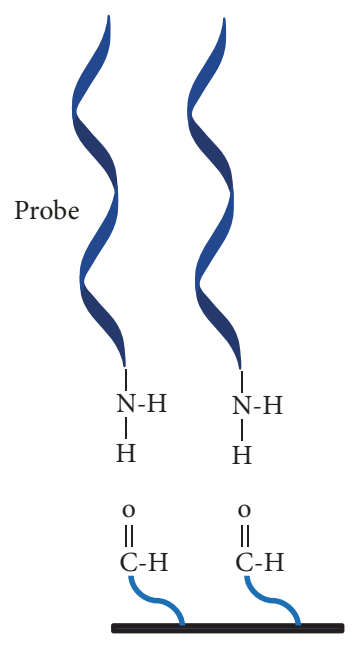

A
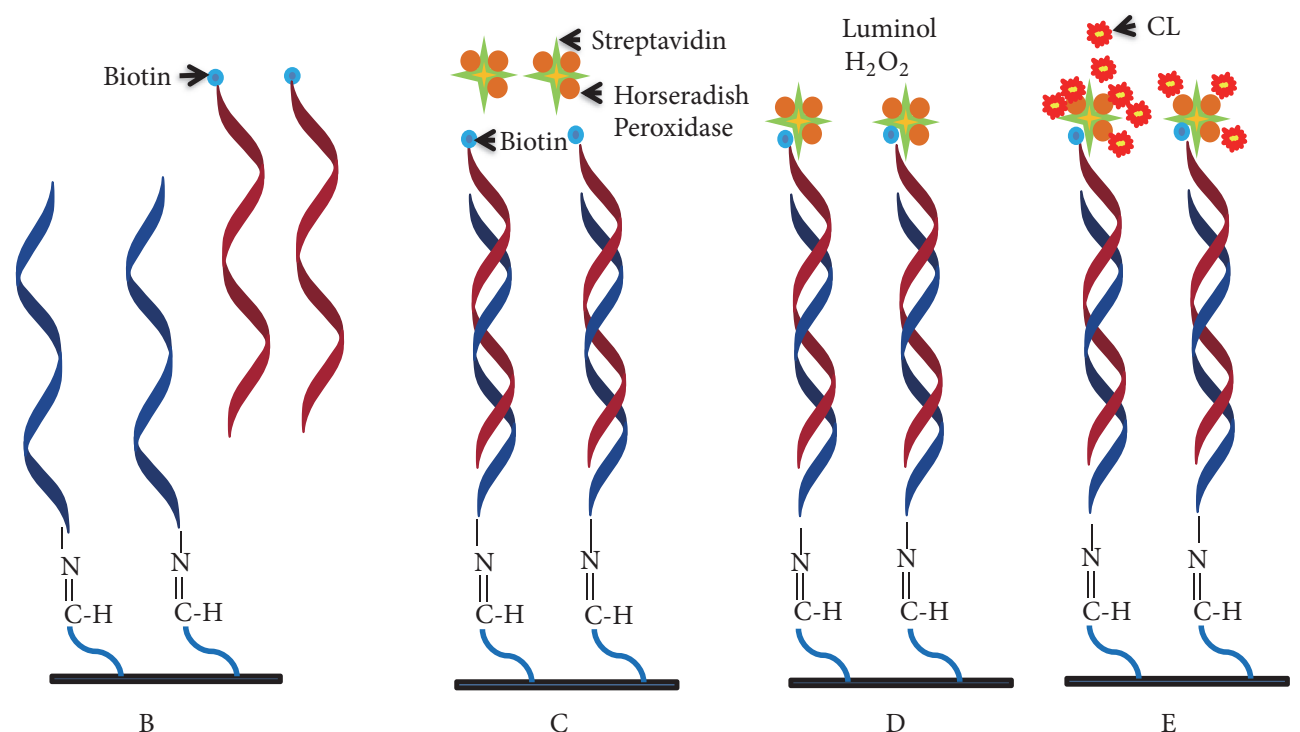

(b)

Figure 1: (a) The microarray layout of the target carbapenemase genes that are detected in this study. (b) Principle of hybridization and CL imaging of microarray. (A) Captured probes were fixed to the aldehyde-chip surface, (B) denatured PCR products were hybridized with capture probes, $(\mathrm{C})$ horseradish peroxidase modified streptavidin was bond to biotin incorporated in hybridization, and (D) adding HRP substrates luminal and $\mathrm{H}_{2} \mathrm{O}_{2}$ and (E) CL signal was detected by catalyzed substrates.

and 16S rRNA were collected from cultured Hela cell and standard strains of Escherichia coli ATCC25922, respectively.

2.5. Microarray Fabrication. All microarray probes were synthesized by the Chinese PLA Academy of Military Medical Sciences. An oligo(dT) $)_{12}$-with an amino-labeled $3^{\prime}$-end was conjugated to the $3^{\prime}$-end of all the probes, such that it served as a linker arm to be immobilized on the aldehyde modified glass surface (Baio Technology Shanghai Co., Ltd., Shanghai, China). An Oligo $(\mathrm{dT})_{20}$ with an amino-labeled $3^{\prime}$-end and a biotin-labeled $5^{\prime}$-end served as a quality control (QC) probe. Each probe ( $50 \mu \mathrm{M}$ of final concentration) was spotted thrice repeatedly by using a noncontact inkjet Nano-plotter 2.1 (GeSim, Dresden, Germany) onto an aldehyde-chip after mixing with printing buffer [5\% glycerol, $0.1 \%$ sodium dodecyl sulfate (SDS), $6 \times$ saline-sodium citrate buffer (SSC), and 2\% (wt/vol) Ficoll 400]. Quality control (QC) probe was included to manage the standard of operation and used at 12.5 $\mu \mathrm{M}$ final concentration. It was spotted eight times repeatedly in the horizontal direction to calibrate the CL signal values. Each aldehyde slide was divided into 10 blocks $(11 \times 11 \mathrm{~mm})$ by a waterproof film to detect 10 different samples. Microarrays were placed in a dryer for $24 \mathrm{~h}$ at room temperature. Unbound probes were washed off by $0.2 \%$ SDS and distilled water prior to use. The layout is shown in Figure 1(a).

2.6. Multiplex PCR. All reverse primers for target genes and internal controls (i.e., mtDNA and $16 \mathrm{~S}$ rRNA) were labeled 
KPC

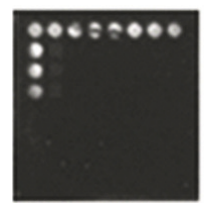

NDM-1

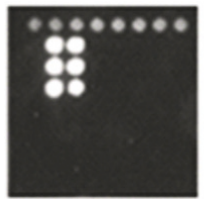

OXA-23

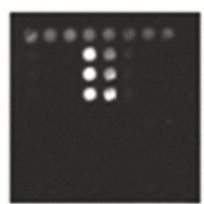

OXA-48

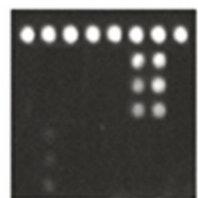

OXA-51

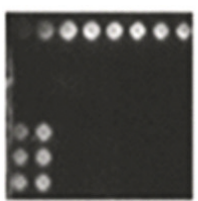

IMP

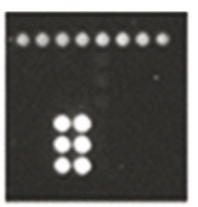

VIM

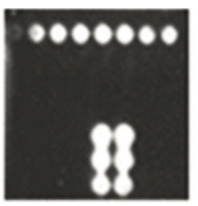

DIM

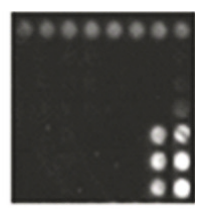

FIGURE 2: Representative microarray hybridization images with the reference carbapenemase plasmids (positive controls).

by biotin at the $5^{\prime}$-ends for acting a CL reaction. Multiplex PCRs were performed for $b l a_{\mathrm{KPC}}, b l a_{\mathrm{OXA}-23}, b l a_{\mathrm{VIM}}, b l a_{\mathrm{DIM}}$, and $16 \mathrm{~S}$ rRNA in one tube (Tube A), and $b l a_{\mathrm{IMP}}, b l a_{\mathrm{NDM}-1}$, $b l a_{\mathrm{OXA}-48}, b l a_{\mathrm{OXA}-51}$, and mtDNA in another (Tube B). PCR reaction was in $30 \mu \mathrm{L}$ and contained $15 \mu \mathrm{L}$ of $2 \times$ Multiplex PCR Mix (cwBiotech, Beijing China) and $3 \mu \mathrm{L}$ of mixed DNA templates. For Tube A, the concentrations of $b l a_{\text {OXA-23 }}$, $b l a_{\mathrm{VIM}}, b l a_{\mathrm{DIM}}$, and $16 \mathrm{~S}$ rRNA forward and reverse primers all were $0.1 \mu \mathrm{M}$ and $0.5 \mu \mathrm{M}$, and for $b l a_{\mathrm{KPC}}$ the forward and reverse primer were $0.2 \mu \mathrm{M}$ and $1 \mu \mathrm{M}$, respectively. For Tube $\mathrm{B}$, the concentrations of the forward and reverse primers were $0.1 \mu \mathrm{M}$ and $0.5 \mu \mathrm{M}$, respectively. PCR was performed on a Thermal Cycler PCR system (Applied Biosystems, Foster City, CA) using the following conditions: $10 \mathrm{~min}$ at $95^{\circ} \mathrm{C} ; 37$ cycles of $30 \mathrm{~s}$ at $94^{\circ} \mathrm{C}, 30 \mathrm{~s}$ at $55^{\circ} \mathrm{C}$, and $45 \mathrm{~s}$ at $72^{\circ} \mathrm{C}$; and a final extension of $5 \mathrm{~min}$ at $72^{\circ} \mathrm{C}$.

2.7. Hybridization and Signal Detection. PCR products amplified by the two multiplex PCR reactions using the same template were mixed. The mixtures were denatured at $95^{\circ} \mathrm{C}$ for $5 \mathrm{~min}$ and placed on ice immediately for $5 \mathrm{~min}$. Then 5 $\mu \mathrm{L}$ of denatured PCR mixtures were blended with $5 \mu \mathrm{L}$ of hybridization buffer [ $8 \times$ SSC, $0.6 \%$ SDS, $10 \%$ formaldehyde, and $10 \times$ Denhardt]. Hybridization reaction was proceeded in a hybrid-box by incubation for $1 \mathrm{~h}$ at $45^{\circ} \mathrm{C}$. After hybridization, slide was washed successively in $1 \times$ SSC and $0.2 \%$ SDS, $0.2 \times$ SSC, and $0.1 \times$ SSC for $30 \mathrm{~s}$. Slide was air dried at room temperature. To detect the CL signals, microarray was incubated in $37^{\circ} \mathrm{C}$ for $30 \mathrm{~min}$ with $10 \mu \mathrm{L}$ of streptavidin horseradish peroxidase (Str-HRP, Sigma-Aldrich, St.Louis, USA), followed by wash with PBST (1×PBS, 0.05\% Tween-20) for $30 \mathrm{~s}$ at room temperature. Dried microarray was covered in $10 \mu \mathrm{L}$ of premixed CL HRP substrate luminal solution and $\mathrm{H}_{2} \mathrm{O}_{2}$ (Millipore Corporation, Boston, USA) (Figure 1(b)). Then immediately subject to scanning by Biochip Chemiluminescence Imager, a microlight level imaging system developed in our laboratory. Signal intensities were calculated by Array Vision 7.0.

\subsection{Identification of Carbapenem-Resistant and Susceptible} Strains. The strains isolated from samples were tested using the Kirby-Bauer (K-B) method of disk diffusion according to the recommendations of the CLSI to determine their susceptibilities to imipenem $(10 \mu \mathrm{g})$ and meropenem $(10 \mu \mathrm{g})$. Escherichia coli ATCC25922 and Pseudomonas aeruginosa ATCC27853 were used as control strains for susceptibility testing. Isolates were considered to have a carbapenemase phenotype if they were resistant to at least one carbapenem (i.e., meropenem or imipenem) [22].
Four hundred sixteen (416) antibiotic-resistant bacterial samples were evaluated in this study. The initial samples were obtained from patients who had been hospitalized for a long time ( $>1$ year).

\subsection{Confirmation of the Resistance Genes by Sequencing.} The resistance genes, including $b l a_{\mathrm{KPC}}, b l a_{\mathrm{NDM}-1}, b l a_{\mathrm{OXA}-23}$, $b l a_{\mathrm{OXA}-48}, b l a_{\mathrm{OXA}-51}, b l a_{\mathrm{IMP}}, b l a_{\mathrm{VIM}}$, and $b l a_{\mathrm{DIM}}$, that had been detected in antibiotic-resistant samples by microarray hybridization were validated by Sanger sequencing.

\section{Results}

3.1. Determination of Threshold Signal Intensity. To determine the threshold value for differentiating positive and negative microarray signal intensities, we have performed pilot microarray hybridization experiments using the Grampositive bacterial strain $S$. aureus 04018 as negative controls and carbapenemase plasmids of $3 \times 10^{3}$ copies/ $\mu \mathrm{L}$ as positive controls under the conditions specified in Materials and methods. If the signal intensity value is 10 times of the background intensity value, the probe was considered to be positive.

3.2. Specificity and Sensitivity of Microarray Test. To evaluate the specificity of the microarray method, we performed microarray hybridization assays for the reference carbapenemase plasmids (i.e., positive controls) (Figure 2), clinical carbapenem-resistant samples (Figure 3), and ten negative controls that were from ATCC standard strains and were sensitive to carbapenem (Figure 4). As shown by the microarray images, our method could effectively distinguish between the carbapenem resistance and carbapenem-sensitive genotypes among the clinical bacterial specimens with high specificity.

To evaluate the sensitivity of the microarray assay, we diluted the reference carbapenemase plasmids into various concentrations (i.e., from $3 \times 10^{1}$ copies/ $\mu \mathrm{L}$ to $3 \times 10^{5}$ copies $/ \mu \mathrm{L})$. The different copy numbers of DNA were hybridized to the microarrays. The detection images were shown in Figure 5(a). In general, the microarrays yielded satisfactory sensitivity. For most reference plasmids, the detection limit was as low as 30 copies/ $\mu \mathrm{L}$ (Figure 5(a)). Diagnostic Kit for Bacterial Resistance Gene KPC (PCRFluorescence Probing) and Diagnostic Kit for Bacterial Resistance Gene NDM-1 (PCR-Fluorescence Probing) (Puruikang Biotech, Shenzhen, China) were also used to detect KPC and NDM-1 reference plasmids $\left(3 \times 10^{1}\right.$ to $3 \times 10^{5}$ copies $\left./ \mu \mathrm{L}\right)$, respectively. Real-time PCR amplified by ABI Prism 7500 real-time PCR apparatus (Applied Biosystems, Foster City, 


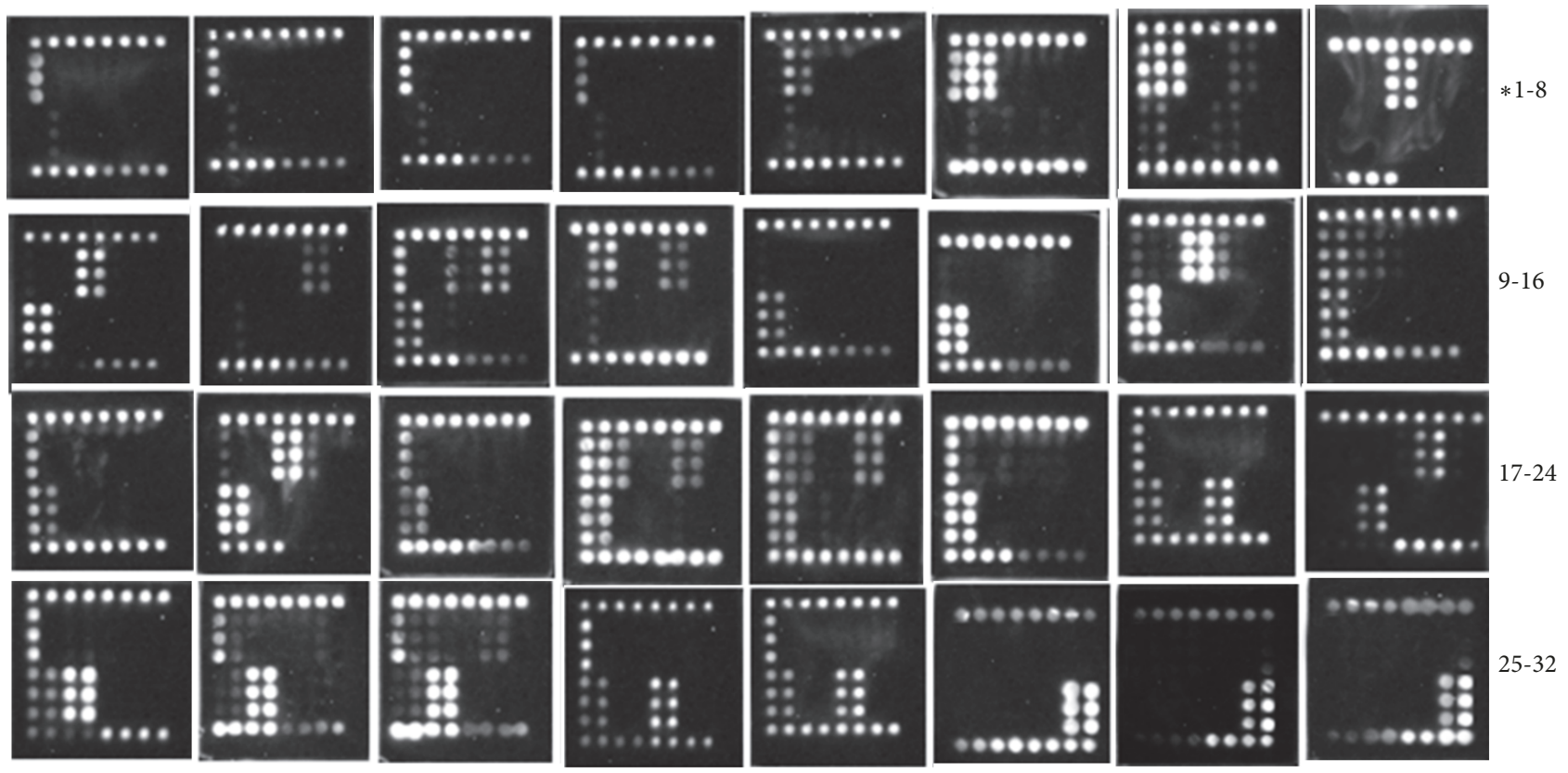

FiguRE 3: Representative images of microarray assays for clinical carbapenemase-producing specimens. *, the number of clinical carbapenemase-producing specimens (Supplementary Table).
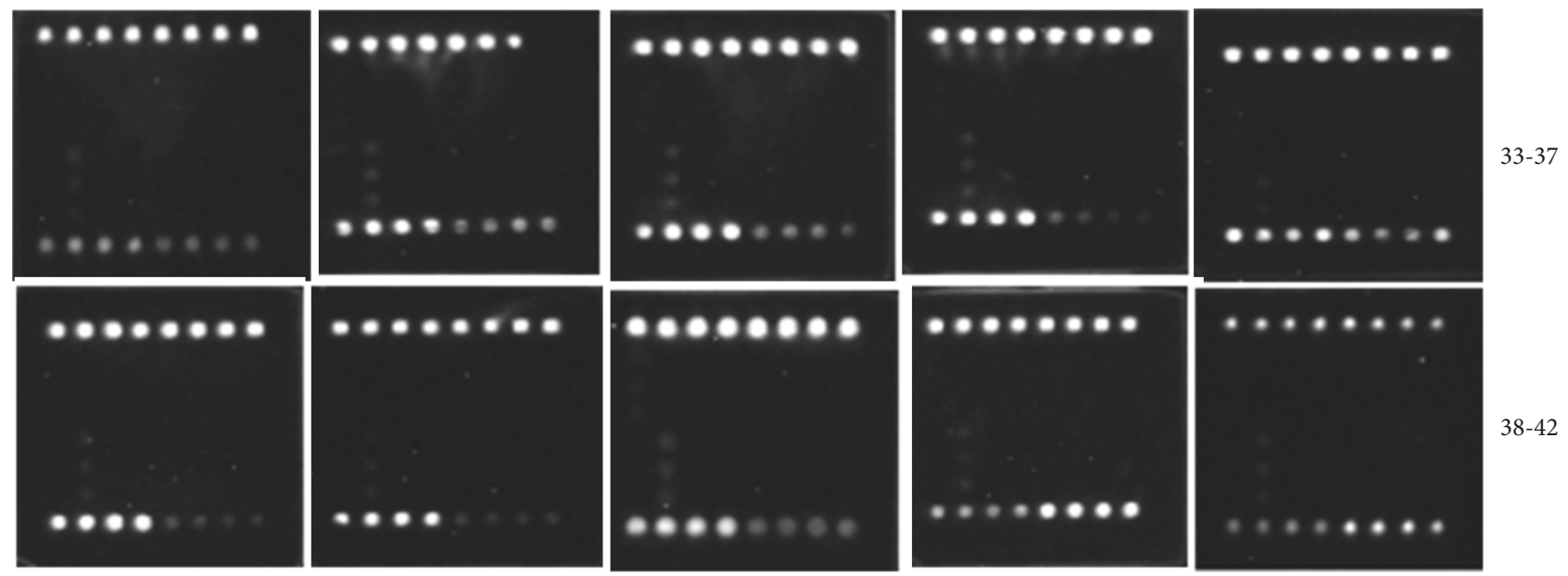

Figure 4: Images of microarray assays for carbapenemase-sensitive strains (negative control strains). 33, Escherichia coli (ATCC 25922); 34, Enterococcus faecium (ATCC 35667); 35, Enterobacter cloacae (ATCC 13047); 36, Enterococcus faecalis (ATCC 29212); 37, Pseudomonas aeruginosa (ATCC 27853); 38, Acinetobacter baumannii (ATCC 19606); 39, Staphylococcus aureus (ATCC25923); 40, Streptococcus pneumoniae (ATCC 49619); 41, Klebsiella pneumonia (ATCC700603); 42, Streptococcus pneumonia (ATCC 9007(serotype C)). ATCC, American Type Culture Collection.

US) and the results of sensitivity comparison between microarray assay and Real-time PCR showed they had similar sensitivities (Figures 5(b) and 5(c)), indicating that our DNA microarrays could be applied to the clinical detection of the carbapenemase-producing samples.

3.3. Stability of Microarray Assay. Diluted carbapenemase plasmids $\left(3 \times 10^{5}\right.$ copies $\left./ \mu \mathrm{L}\right)$ and negative controls $S$. aureus 04018 were used to evaluate how the microarray assays performed as far as repeatability is concerned. The $3 \times 10^{3}$ copy $/ \mu \mathrm{L}$ plasmid of each target gene was selected as the template to detect for the determination of interchip and intrachip variation, and a negative control was set up without template. The experiment was repeated three times, and the repeatability of interchip and intrachip variation were evaluated. Coefficient of variation $(\mathrm{CV})=\mathrm{SD} /$ mean of signal intensities $\times 100 \%$.

Statistical analysis showed that, for all target gene probes, the intrachip and interchip CV values of 8 probes ranged from $3.58 \%$ to $11.02 \%$ (below $15 \%$ ), suggesting a favorable repeatability of the DNA microarray detection method (Table 3). 


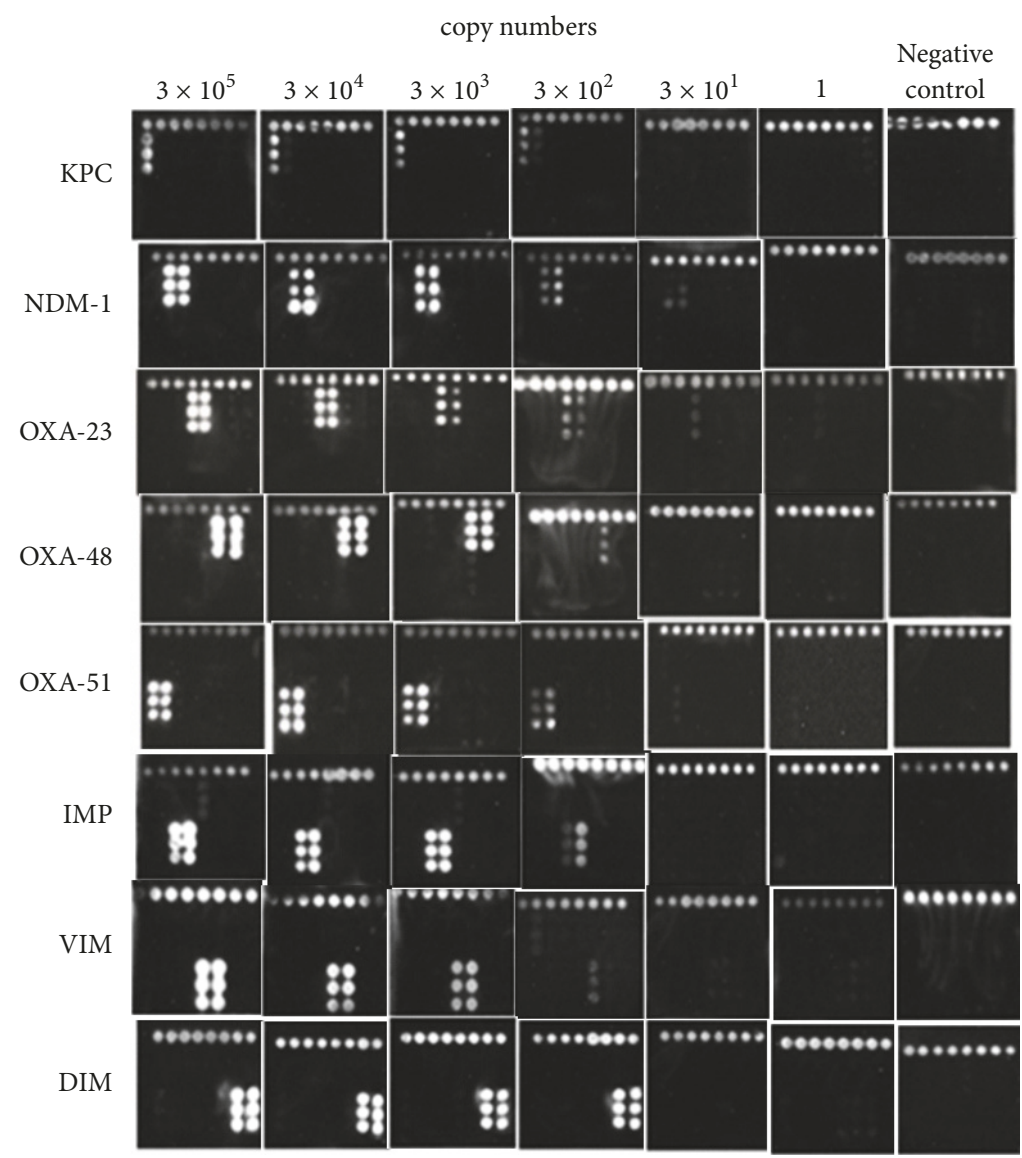

(a)

KPC

Amplification Plot

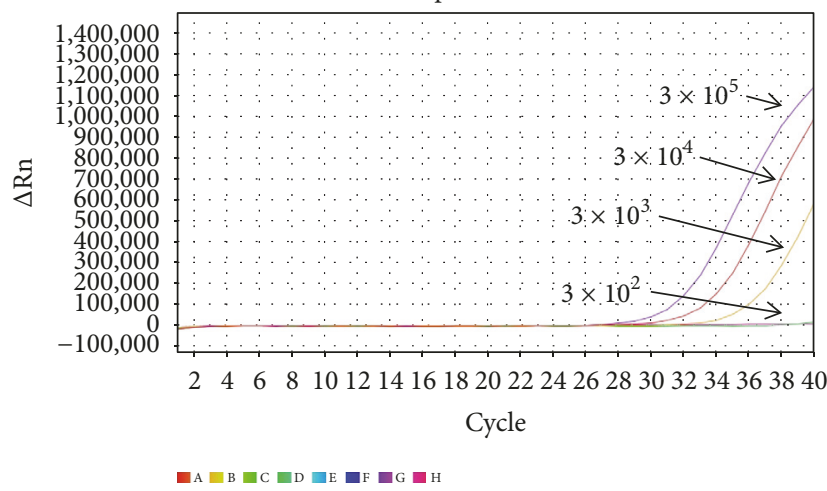

(b)

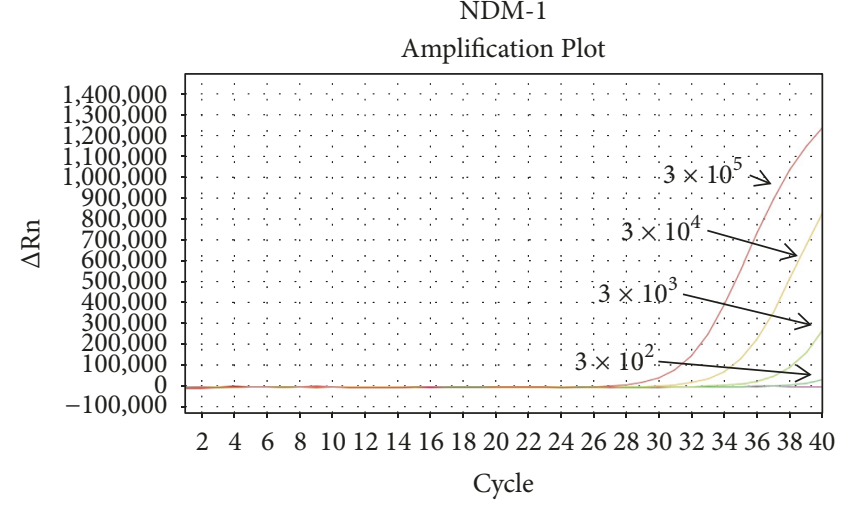

(c)

FIGURE 5: (a) Sensitivity of the microarray assays. The indicated carbapenemase reference plasmids were subject to series dilutions and hybridized to the DNA microarrays. The plasmids copy numbers are diluted from $3 \times 10^{1}$ to $3 \times 10^{5}$ copies $/ \mu \mathrm{L}$. (b) KPC reference plasmids $\left(3 \times 10^{1}\right.$ to $3 \times 10^{5}$ copies $\left./ \mu \mathrm{L}\right)$ were detected by real-time PCR, (c) NDM-1 reference plasmids $\left(3 \times 10^{1}\right.$ to $3 \times 10^{5}$ copies $\left./ \mu \mathrm{L}\right)$ were detected by real-time PCR.

3.4. Phenotypic Resistance. About $78 \%$ clinical specimens (326/416) were resistant to both imipenem and meropenem, 77 samples were susceptible to both imipenem and meropenem, three samples were resistant to imipenem but sensitive to meropenem, and five samples were reversely sensitive to imipenem but resistant to meropenem as well as five samples were intermediary to imipenem but sensitive to meropenem. Most carbapenem-resistant samples were nonsusceptible to diverse antibiotics containing cephalosporins, fluoroquinolone, aminoglycosides, etc. The rates of nonsusceptibility to different antimicrobial agents were commonly $>90 \%$. Clinical information and phenotypic 
TABLE 3: Statistics of the microarray repeatability.

\begin{tabular}{lcccc}
\hline & \multicolumn{3}{c}{$\begin{array}{c}\text { Repeatability (CV\%) } \\
\text { Intra-chip experiments }\end{array}$} & Inter-chip experiment \\
\hline Repeat times (n) & 1 & 2 & 3 & 10.16 \\
\hline KPC & 5.23 & 4.75 & 9.85 & 6.71 \\
NDM-1 & 3.67 & 4.12 & 6.44 & 7.54 \\
OXA-23 & 4.47 & 5.03 & 7.82 & 6.42 \\
OXA-48 & 3.58 & 3.87 & 6.83 & 7.88 \\
OXA-51 & 4.45 & 5.31 & 10.24 & 11.02 \\
IMP & 6.84 & 6.95 & 9.97 & 10.19 \\
VIM & 5.87 & 6.04 & 6.52 & 6.67 \\
DIM & 4.02 & 3.89 & & \\
\end{tabular}

results of all clinical samples were shown in Supplementary Table (available here).

3.5. Detection of Carbapenemase-Producing Strains by Microarray in Clinical Samples. A total of 416 clinical samples collected from Chinese PLA General Hospital were tested. The majority of the samples had previously been well-characterized as carbapenem resistance using K-B method. The microarrays for these bacteria revealed that $78 \%$ (325) of the samples carried one or more carbapenemase genes and that in some samples more than one bla gene had been identified (i.e., 496 genes were found in 325 specimens). The genotyping results of the clinical samples are listed as follows: $256(62 \%)$ carried bla $a_{\mathrm{KPC}}, 137$ (33\%) carried $b l a_{\mathrm{OXA}-51}, 40(9.6 \%)$ carried $b l a_{\mathrm{OXA}-23}, 22(5.3 \%)$ carried $b l a_{\mathrm{OXA}-48}, 27(6.5 \%)$ carried $b l a_{\mathrm{NDM}-1}, 5(1.2 \%)$ carried $b l a_{\mathrm{IMP}}$, $3(0.7 \%)$ carried $b l a_{\mathrm{VIM}}$, and $6(1.4 \%)$ carried $b l a_{\mathrm{DIM}}$ (Table 4$)$. Therefore, $b l a_{\mathrm{KPC}}$ was the most frequent carbapenemase gene found in the antibiotic-resistant sample. Most interestingly, we found that $b l a_{\text {OXA-51 }}$ frequently coexisted with other bla genes. For example, 89 samples that carried $b l a_{\mathrm{KPC}}$ also carried $b l a_{\mathrm{OXA}-51}$; all 40 samples of bla $a_{\mathrm{OXA}-23}$ carried $b l a_{\mathrm{OXA}-51} ; 9$ samples carried all three bla genes: $b l a_{\mathrm{KPC}}$, $b l a_{\mathrm{OXA}-51}$, and $b l a_{\mathrm{OXA}-23}$; and 5 samples carrying $b l a_{\mathrm{OXA}-48}$ also carried both $b l a_{\mathrm{OXA}-51}$ and $b l a_{\mathrm{KPC}}$. It is worth noting that all carbapenemase genes in the 325 antibiotic-resistant samples had been verified by sequencing. In parallel, we also amplified the isolates that were susceptible to carbapenems performed in phenotypic tests as well as recruited in our microarray assays. The overall concordance between the microarray-based assay and the reference methods (standard DNA sequencing) was $97.8 \%$, suggesting that our microarray is a highly reliable method for detecting the carbapenemase-producing GNB in the clinic.

Fourteen samples which failed to detect any genes by microarray but resistant to either imipenem or meropenem in phenotypic test could not be amplified, determining $96.6 \%$ concordance between the phenotypic and microarray tests. Taken together, the newly developed microarray detection method is comparable to the conventional antibiotic susceptibility test and therefore may be suitable for clinical applications.

\section{Discussion}

In this study, we developed a novel microarray method to detect carbapenemase genes that could be applied to clinical diagnosis and identification of carbapenemase-producing GNB. We included eight carbapenemase genes that have been shown or potential display to be most clinically relevant, $b l a_{\mathrm{KPC}}, b l a_{\mathrm{NDM}-1}, b l a_{\mathrm{OXA}-23}, b l a_{\mathrm{OXA}-48}, b l a_{\mathrm{OXA}-51}, b l a_{\mathrm{IMP}}$, $b l a_{\mathrm{VIM}}$, and $b l a_{\mathrm{DIM}}$, in the design of the microarray chips. MtDNA and 16S rRNA were chosen as internal controls because our samples were taken from human and the detected target genes were from bacteria. The high copy number sequence of mtDNA was used to monitor and control all PCR reactions and hybrids operations, and $16 \mathrm{~S}$ rRNA was used to prove that the DNA microarray system could detect bacterial genes from all samples. The specificity, sensitivity, and reproducibility of the proposed method were highly favorable for clinical applications. Most importantly, the microarray results of the 416 clinical samples showed highly consistent agreement with results obtained from direct sequencing or antibiotic susceptibility tests.

It was intriguing for us to identify a number of resistant strains coharboring two or more carbapenemase genes; for instance, $b l a_{\mathrm{KPC}}$ frequently coexisted with other genes and $b l a_{\mathrm{OXA}-51}$ always coexisted with bla $a_{\mathrm{OXA}-23}$ in Acinetobacter bau mannii, indicating a more serious threat than before, when it came to the control and management of the extremely drug-resistant bacterial infections [23]. Of the transferable molecular class B metallo- $\beta$-lactamases, IMP, VIM, and NDM were common, while DIM was endemic [10]. However, in our study, $b l a_{\mathrm{IMP}}$ and $b l a_{\mathrm{VIM}}$ were detected in 5 and 3 samples, respectively, yet $b l a_{\mathrm{DIM}}$ was in 6 specimens, which indicated that it might be necessary to improve the attention for DIM in the later study (Table 4 and Supplementary Table).

The DNA microarray could detect bacterial carbapenemase genes from not only clinical sputum, urine samples, and colony or bacterial culture in this study, but also specimens of pleural effusion, cerebrospinal fluid, oral swab, and throat swab even environmental swab (data not shown) directly. This remarkable capability of compatibility to detect of several original samples made it faster to obtain result than similar microarrays Check-MDR CT102 [24, 25] and VITEK2 [26] that should detect cultured bacterial isolates. 


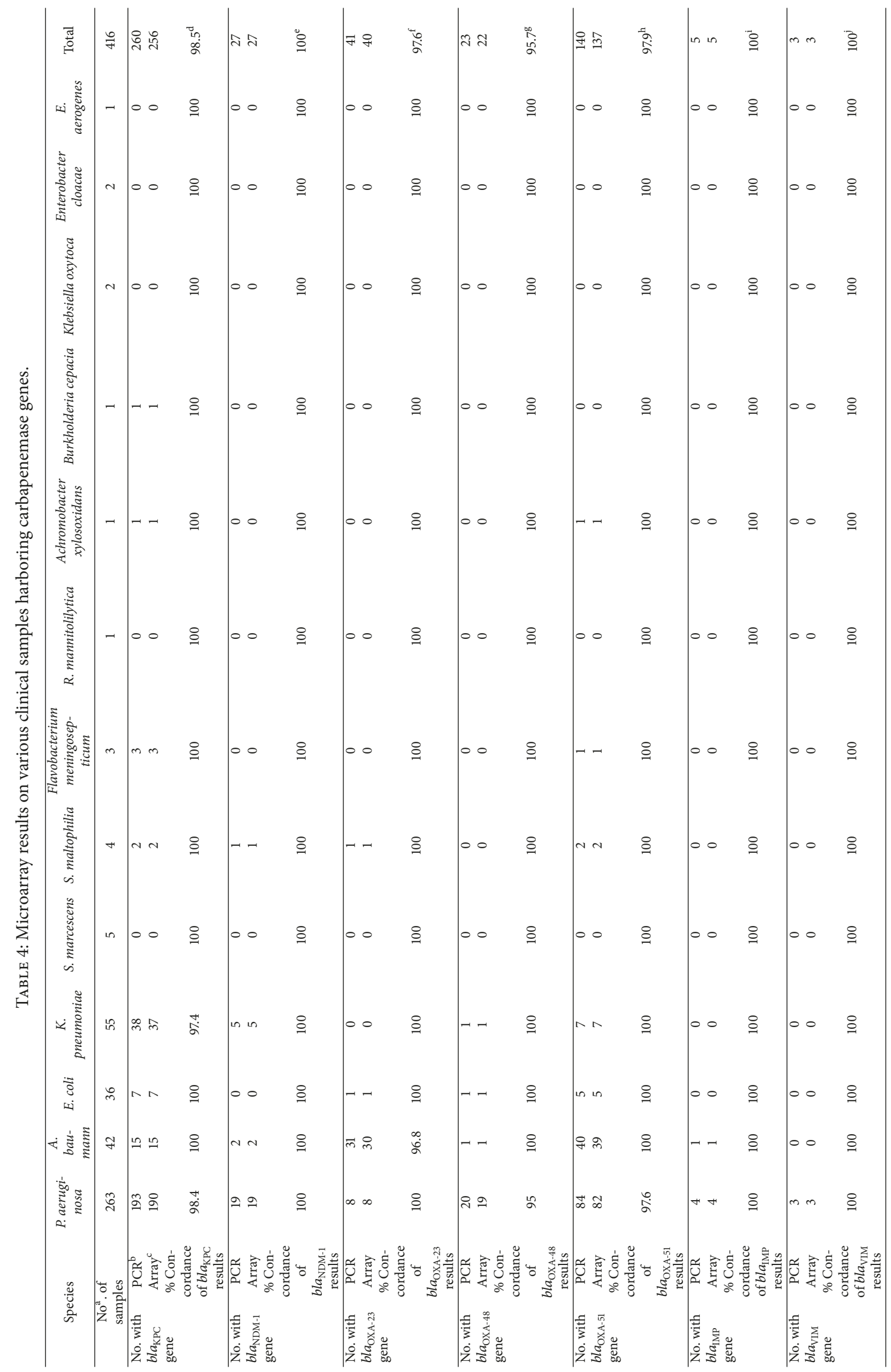




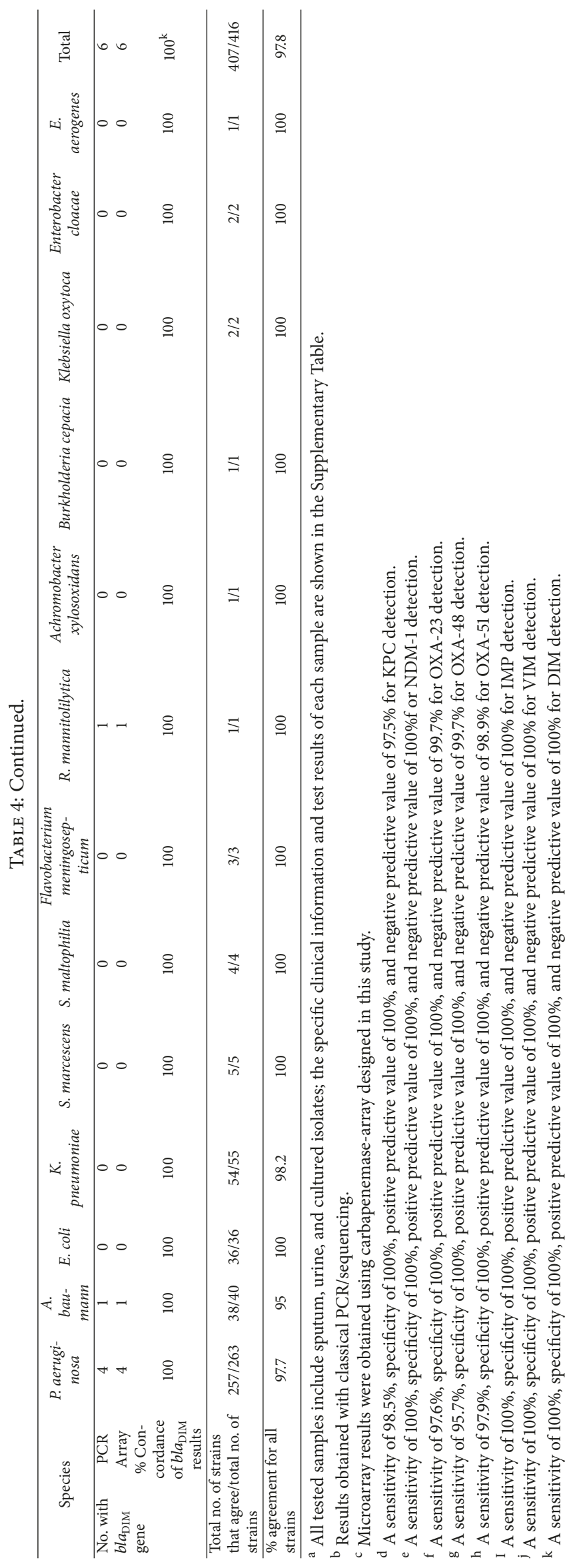


The microarray was rapid and portable, when starting from the clinical sample, less than 7 hours with overall 2 hours of hands-on time, enabling one day analysis. Whole detection operation of the DNA microarray consisted of 5 steps and costs 4-5 h including PCR amplification, and whole detection did not need sophisticated instrument, which was far simpler than Check-MDR CT102. The DNA microarray could detect 9 specimens at one chip one time and the cost per sample was below five dollars, which was far cheaper than Check-MDR CT102 and VITEK2. In microarray assay, a proprietary CL imaging system was developed in our laboratory. The Biochip Chemiluminescence Imager relied on charge-coupled device (CCD) camera imaging technology and equipped with a power supply unit for portable use. The new CL imager had a lower cost $(\$ 3000)$ than other commercial CCD imaging technology CL imagers (e.g., Amersham Imager 600, GE Healthcare Life Sciences) and much faster than other visual microarray system which was based on quantum dot-catalyzed silver deposition. The newly designed DNA microarray system had yielded high specificity, sensitivity, and reproducibility in detecting the eight carbapenemase genes among the clinical specimens. For $b l a_{\mathrm{NDM}-1}, b l a_{\mathrm{OXA}-23}, b l a_{\mathrm{OXA}-48}, b l a_{\mathrm{OXA}-51}, b l a_{\mathrm{IMP}}, b l a_{\mathrm{VIM}}$, and $b l a_{\text {DIM }}$, there were two different probes (22-30 nt) designed to hybridize, respectively, which could effectively minimize the false hybridization signals. Our study has demonstrated that the microarrays with greatly simplified the protocol to determine the cabapenemase-encoding genes in the clinical samples and can offer an efficient means for the molecular epidemiological studies of cabapenemase genes: the emergence of the resistant genes may potentially be traced back to their origins where community- and hospitalbased bacterial infections were frequently happening. On the other hand, microarray hybridization is highly sensitive. In this study, they showed similar sensitivities as the real-time PCR kit. We could detect as low as 30 copies $/ \mu \mathrm{L}$ of DNA targets. Furthermore, the DNA microarrays can generally detect target DNAs with much larger dynamic ranges. Finally, the microarray method is also highly reproducible: we have shown that the averaged coefficient of variations (CV \%) for interchip and intrachip experiments were low, and most of them were less than $10 \%$. Therefore, we propose that the new microarray method has a great potential to be applied to clinical studies.

The microarray based on multi-PCR, which made it possible to detect multiple resistant genes at the same time in a single tube. But it could not effectively identify a variety of fragments by electrophoretic separation. Direct sequencing of DNA is not suitable for identification of multiple PCR products. The microarray is used to confirm the results of multiple PCR. The concordance of microarray to PCR of detection 8 carbapenemase genes ranges from $95.7 \%-100 \%$ (Table 4).

The microarray had some limitations, because resistance to carbapenems in particular was produced through several mechanisms: such as synthesis of carbapenem $\beta$-lactamases, efflux pumps [27], loss of membrane permeability [28], and penicillin-binding proteins variants. The DNA microarray could not cover genes form all the mechanisms. Fourteen samples in our study which failed to detect any genes by microarray but resistant to either imipenem or meropenem in phenotypic test could not be amplified, indicating resistant genes from other mechanisms were beyond of detection reach of the microarray. Whole genome sequencing (WGS) has potential to detect many different molecular mechanisms leading to resistance. Our lab has taken WGS as new powerful technology to find novel resistant genes located in bacterial plasmid or genome DNA, as well as new resistant mechanisms. However, WGS-based antimicrobial susceptibility testing in clinical laboratories remain the current highcost and taking more time [29]. In clinical testing, using PCR-based microarray to detect some specific resistance genes simultaneously was more economical and faster. In this study, multi-PCR amplification was divided into two tubes, and reducing PCR amplification systems (amplifying 8 carbapenemase genes in one tube) might increase sensitivity [30].

In conclusion, we developed a new microarray detection system that could directly detect eight carbapenemase genes from several kinds of clinical specimens. It was convenient, readily to be customized for high-throughput detection, and could be easily adapted for clinical applications.

\section{Data Availability}

The date generated and analyzed during this study are available from the corresponding author on reasonable request.

\section{Disclosure}

The funder had no role in study design, data collection and analysis, decision to publish, or preparation of the manuscript.

\section{Conflicts of Interest}

The authors declare that the research was conducted in the absence of any commercial or financial relationships that could be construed as potential conflicts of interest.

\section{Authors' Contributions}

Yi Song and Fengna Dou contributed equally as first authors. Qiqi Liu and Yu Zhou conceived and designed the study. Yi Song, Fengna Dou, Sha He, and Qiqi Liu were responsible for the experimental analysis. Yi Song wrote the paper and other coauthors contributed to the final draft. All authors read and approved the final manuscript.

\section{Acknowledgments}

Thanks are due to the team of People's Liberation Army 301 Hospital of China and the Cancer Hospital of Chinese Academy of Medical Sciences and Peking Union Medical College. This work was financially supported by Major Special Projects on Infectious Diseases of China 
(no. 2013ZX10004802-008) and National Science and Technology Major Project "Prevention and Control of Major Infectious Diseases such as AIDS and Viral Hepatitis" (no. 2018ZX10711001-003-003).

\section{Supplementary Materials}

Additional file 1: Supplementary Table. Clinical information and detection results of carbapenemase-producing samples. (Supplementary Materials)

\section{References}

[1] S. D. Braun, O. S. Dorneanu, T. Vremeră, A. Reißig, S. Monecke, and R. Ehricht, "Carbapenemase-producing Enterobacteriaceae: a 2-year surveillance in a hospital in Iaşi, Romania," Future Microbiology, vol. 11, no. 3, pp. 391-401, 2016.

[2] S. Kuo, Y. Lee, S. Yang et al., "Eradication of multidrugresistant Acinetobacter baumannii from the respiratory tract with inhaled colistin methanesulfonate: a matched case-control study," Clinical Microbiology and Infection, vol. 18, no. 9, pp. 870876, 2012.

[3] A. Carricajo, P. O. Verhoeven, S. Guezzou, N. Fonsale, and G. Aubert, "Detection of carbapenemase-producing bacteria by using an ultra-performance liquid chromatographytandem mass spectrometry method," Antimicrobial Agents and Chemotherapy, vol. 58, no. 2, pp. 1231-1234, 2014.

[4] CLSI, Performance Standards for Antimicrobial Susceptibility Testing, Clinical and Laboratory Standards Institute, Pa, USA, 27th edition, 2017.

[5] P. Nordmann and L. Poirel, "Strategies for identification of carbapenemase-producing enterobacteriaceae," Journal of Antimicrobial Chemotherapy, vol. 68, no. 3, pp. 487-489, 2013.

[6] P. Wang, S. Chen, Y. Guo et al., "Occurrence of false positive results for the detection of carbapenemases in carbapenemasenegative Escherichia coli and Klebsiella pneumoniae isolates," PLoS ONE, vol. 6, no. 10, p. e26356, 2011.

[7] D. Rawat and D. Nair, "Extended-spectrum B-lactamases in gram negative bacteria," Journal of Global Infectious Diseases, vol. 2, no. 3, pp. 263-274, 2010.

[8] D. van Duin and Y. Doi, "The global epidemiology of carbapenemase-producing Enterobacteriaceae," Virulence, vol. 8, no. 4, pp. 460-469, 2017.

[9] P. Nordmann, T. Naas, and L. Poirel, "Global spread of carbapenemase producing Enterobacteriaceae," Emerging Infectious Diseases, vol. 17, no. 10, pp. 1791-1798, 2011.

[10] S.-S. Jean, W.-S. Lee, C. Lam, C.-W. Hsu, R.-J. Chen, and P.R. Hsueh, "Carbapenemase-producing Gram-negative bacteria: current epidemics, antimicrobial susceptibility and treatment options," Future Microbiology, vol. 10, no. 3, pp. 407-425, 2015.

[11] L. Poirel, J. M. Rodriguez-Martinez, N. Al Naiemi, Y. J. DebetsOssenkopp, and P. Nordmann, "Characterization of DIM-1, an integron-encoded metallo- $\beta$-lactamase from a Pseudomonas stutzeri clinical isolate in the Netherlands," Antimicrobial Agents and Chemotherapy, vol. 54, no. 6, pp. 2420-2424, 2010.

[12] T. A. Leski, U. Bangura, D. H. Jimmy et al., "Identification of blaOXA-51-like, blaOXA-58, blaDIM-1, and blaVIM carbapenemase genes in hospital enterobacteriaceae isolates from sierra leone," Journal of Clinical Microbiology, vol. 51, no. 7, pp. 24352438, 2013.
[13] P. Li, W. Niu, H. Li et al., "Rapid detection of Acinetobacter baumannii and molecular epidemiology of carbapenemresistant A. baumannii in two comprehensive hospitals of Beijing, China," Frontiers in Microbiology, vol. 6, p. 997, 2015.

[14] S. Ji, Y. Chen, Z. Ruan et al., "Prevalence of carbapenemhydrolyzing class D $\beta$-lactamase genes in Acinetobacter spp. isolates in China," European Journal of Clinical Microbiology \& Infectious Diseases, vol. 33, no. 6, pp. 989-997, 2014.

[15] G. Patel and R. A. Bonomo, "Status report on carbapenemases: challenges and prospects," Expert Review of Anti-infective Therapy, vol. 9, no. 5, pp. 555-570, 2011.

[16] T. Chen, Y. Lee, S. Kuo et al., "Emergence and distribution of plasmids bearing the blaOXA-51-like gene with an upstream ISAbal in carbapenem-resistant acinetobacter baumannii isolates in Taiwan," Antimicrobial Agents and Chemotherapy, vol. 54, no. 11, pp. 4575-4581, 2010.

[17] Y. Lee, S. Kuo, M. Chiang et al., " Emergence of CarbapenemResistant Non-baumannii Species of Acinetobacter Harboring a bla OXA-51 -Like Gene That Is Intrinsic to A. baumannii ", Antimicrobial Agents and Chemotherapy, vol. 56, no. 2, pp. 11241127, 2012.

[18] B. A. Evans and S. G. B. Amyes, “OXA $\beta$-lactamases," Clinical Microbiology Reviews, vol. 27, no. 2, pp. 241-263, 2014.

[19] D. Mazzatti, F.-L. Lim, A. O’Hara, I. S. Wood, and P. Trayhurn, "A microarray analysis of the hypoxia-induced modulation of gene expression in human adipocytes," Archives of Physiology and Biochemistry, vol. 118, no. 3, pp. 112-120, 2012.

[20] K. A. Kolquist, R. A. Schultz, A. Furrow et al., "Microarraybased comparative genomic hybridization of cancer targets reveals novel, recurrent genetic aberrations in the myelodysplastic syndromes," Cancer Genetics, vol. 204, no. 11, pp. 603628, 2011.

[21] E. C. Chen, S. A. Miller, J. L. DeRisi, and C. Y. Chiu, "Using a pan-viral microarray assay (Virochip) to screen clinical samples for viral pathogens," Journal of Visualized Experiments, no. 50, 2011.

[22] D. L. Paterson, "Resistance in gram-negative bacteria: enterobacteriaceae," American Journal of Medicine, vol. 119, no. 6, pp. S20-S28, 2006.

[23] C. Rizek, L. Fu, L. C. dos Santos et al., "Characterization of carbapenem-resistant Pseudomonas aeruginosa clinical isolates, carrying multiple genes coding for this antibiotic resistance," Annals of Clinical Microbiology and Antimicrobials, vol. 13, no. 43, 2014.

[24] T. Naas, G. Cuzon, P. Bogaerts, Y. Glupczynski, and P. Nordmann, "Evaluation of a DNA microarray (check-MDR CT102) for rapid detection of TEM, SHV, and CTX-M extendedspectrum $\beta$-lactamases and of KPC, OXA-48, VIM, IMP, and NDM-1 carbapenemases," Journal of Clinical Microbiology, vol. 49, no. 4, pp. 1608-1613, 2011.

[25] J. Cohen Stuart, G. Voets, J. Scharringa, A. C. Fluit, and M. A. Leverstein-Van Hall, "Detection of carbapenemase-producing Enterobacteriaceae with a commercial DNA microarray," Journal of Medical Microbiology, vol. 61, no. 6, pp. 809-812, 2012.

[26] S. Dally, K. Lemuth, M. Kaase, S. Rupp, C. Knabbe, and J. Weile, "DNA microarray for genotyping antibiotic resistance determinants in Acinetobacter baumannii clinical isolates," Antimicrobial Agents and Chemotherapy, vol. 57, no. 10, pp. 4761-4768, 2013.

[27] B. D. Ling, L. Zhang, and X. Z. Li, "Antimicrobial resistance and drug efflux pumps in Acinetobacter," in Efflux-Mediated 
Antimicrobial Resistance in Bacteria, X. Z. Li, C. Elkins, and H. Zgurskaya, Eds., pp. 329-358, Springer International Publishing, Cham, Switzerland, 2016.

[28] E. Fonseca, E. Scheidegger, F. S. Freitas, R. Cipriano, and A. C. Vicente, "Carbapenem-resistant Acinetobacter baumannii from Brazil: role of carO alleles expression and blaOXA-23 gene," BMC Microbiology, vol. 13, no. 1, p. 245, 2013.

[29] M. Ellington, O. Ekelund, F. Aarestrup et al., "The role of whole genome sequencing in antimicrobial susceptibility testing of bacteria: report from the EUCAST Subcommittee," Clinical Microbiology and Infection, vol. 23, no. 1, pp. 2-22, 2017.

[30] Y. Zhang, Q. Liu, D. Wang, S. Chen, X. Wang, and S. Wang, "Genotyping and detection of common avian and human origin-influenza viruses using a portable chemiluminescence imaging microarray," SpringerPlus, vol. 5, no. 1, p. 1871, 2016. 


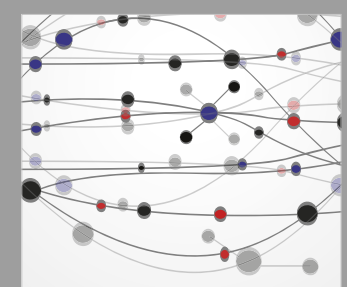

The Scientific World Journal
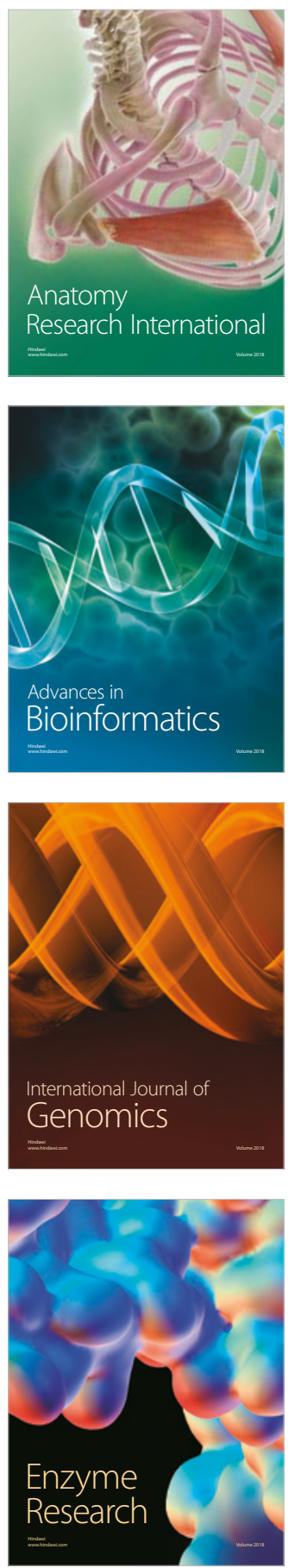
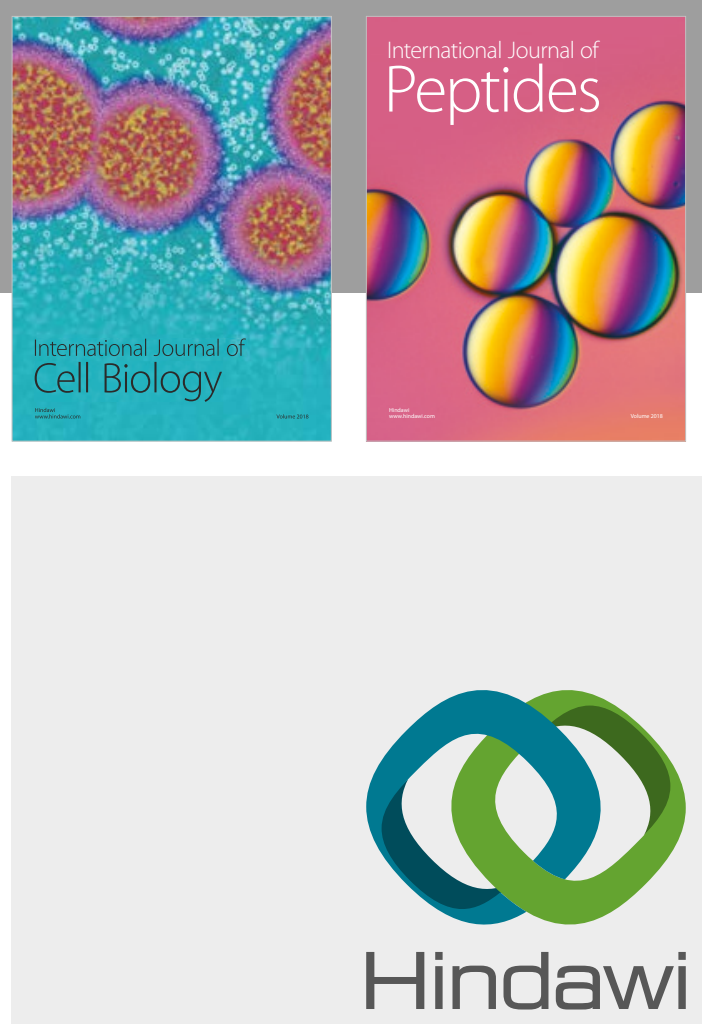

Submit your manuscripts at

www.hindawi.com
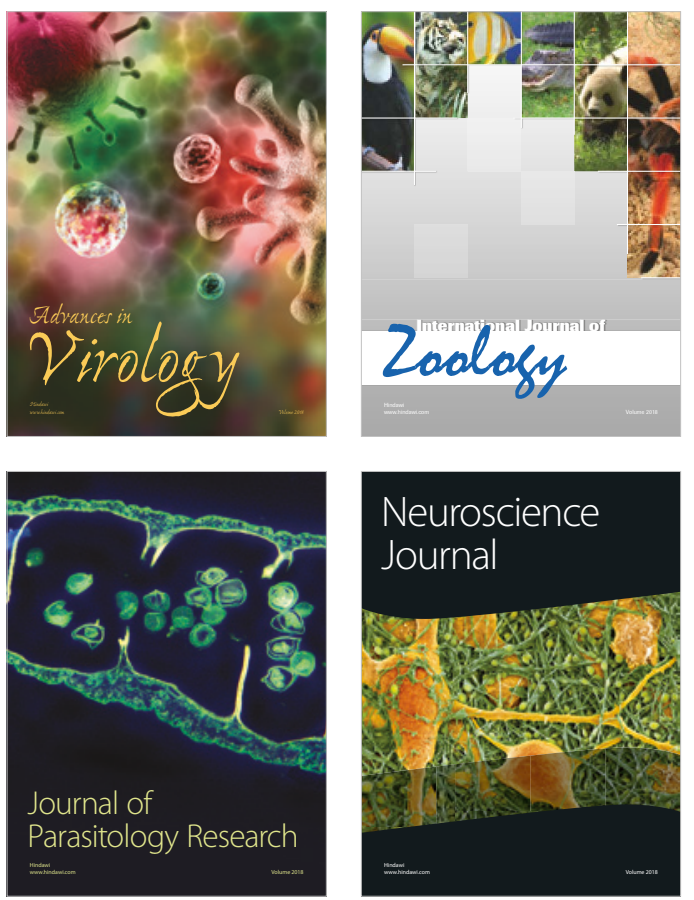
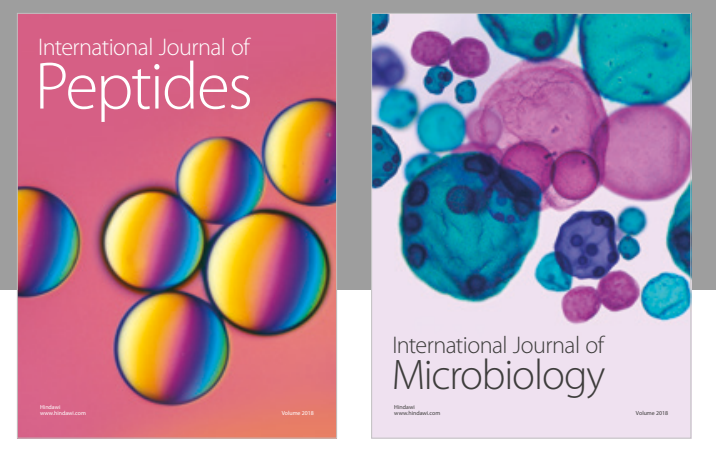

nternational Journal of Microbiology
Journal of
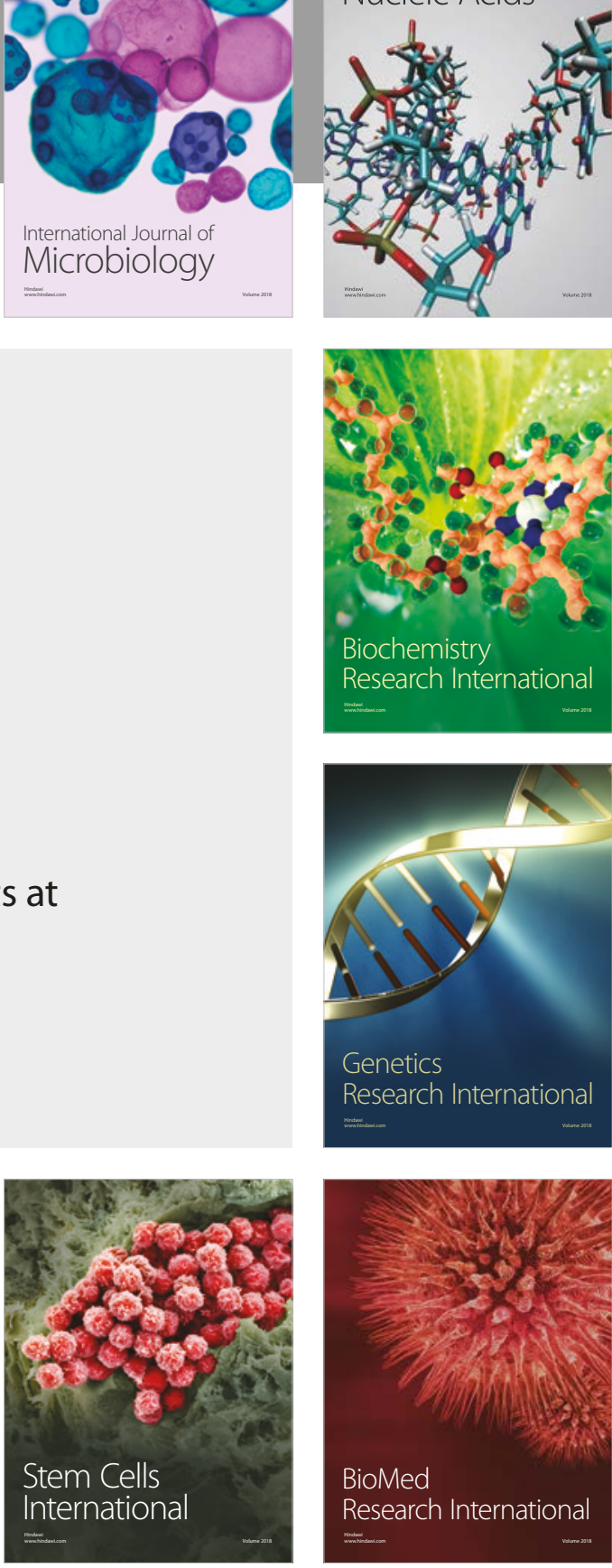
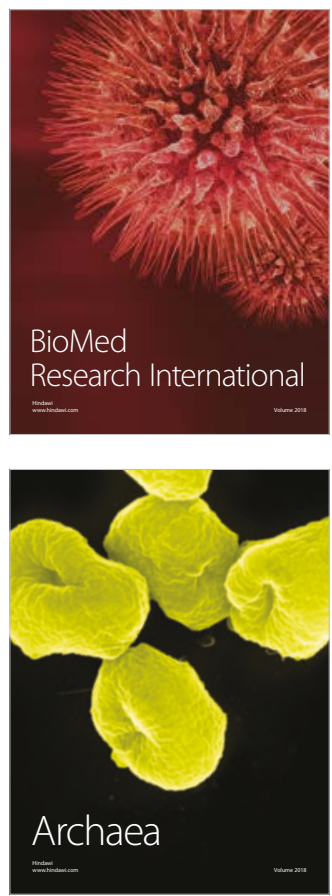